\title{
Variation in Runoff and Sediment Loss in Fallow and Abandoned Farmland in Agoi- Ekpo, Cross River State, Nigeria
}

\author{
1*IWARA, AI; ${ }^{2}$ ABALAKA, LD; ${ }^{3}$ AJISEGIRI, MS \\ ${ }^{1}$ Dept. of Geography \& Environmental Management, University of Abuja. \\ ${ }^{2}$ Department of Architecture, Kaduna State University Kafanchan Campus, Nigeria \\ ${ }^{3}$ Centre for Environmental Studies \& Sustainable Development, Lagos State University Ojo \\ *Corresponding Author Email: iwaradream2008@gmail.com
}

\begin{abstract}
A study was carried out to assess soil erosion and associated losses on abandoned cassava farmland, 3-year, 10-year and 5-year fallows in a part of the rainforest zone of southern Nigeria. The study showed that the 5year fallow yielded the most losses as a result of its scanty herbaceous cover and existence of canopy gaps followed by the abandoned cassava farmland, while the 10-year experienced the lowest losses in runoff and sediment. Runoff loss $(\mathrm{F}=16.089 ; \mathrm{p}<0.05)$ and sediment $\operatorname{loss}(\mathrm{F}=6.355, \mathrm{p}<0.05)$ varied significantly among the treatments. The study revealed erosional losses occurred in all plots and that fallows with sparse herbaceous cover were less effective in suppressing soil erosion. To reduce unproductive loss of rich topsoil, farmers were encouraged to maintain adequate herbaceous cover during cropping to speed up ecological restoration after land abandonment.
\end{abstract}

\section{DOI: https://dx.doi.org/10.4314/jasem.v22i8.35}

Copyright: Copyright (C) 2018 Iwara et al. This is an open access article distributed under the Creative Commons Attribution License (CCL), which permits unrestricted use, distribution, and reproduction in any medium, provided the original work is properly cited.

Dates: Received: 29 July 2018; Revised: 28 August: 2018; Accepted: 31 August 2018

Keywords: Fallow vegetation, Soil erosion, Erosional losses

All over the world, soil erosion is a serious environmental problem with a degrading effect especially on land which is vital resource for agricultural production (Iwara, 2014). In tropical Africa, soil erosion remains a serious problem (Lal, 1989). The degrading strength of soil erosion is dependent on several factors like type of soil, landscape, rainfall, type of vegetation, system of farm management and topographic characteristics (Ezemonye and Emeribe, 2012; Jourgholami et al., 2017). In the tropics, the erosive force of soil erosion is largely caused by rainfall; as such, geomorphologists have used several attributes of rainfall such as kinetic energy, frequency of fall, drop size, intensity of rainfall and rainfall duration among others to study soil erosion (Daura, 1995; Ezemonye and Emeribe, 2012) and reference was made to vegetation cover alone neglecting other vegetation components such as ground cover (undergrowth), girth, basal cover, litter depth, herbaceous composition among others that could have significant effect on soil erosion.

Rainfall and land cover are known to influence soil erosion and associated losses (Daura, 1995; VásquezMéndez et al., 2010; Iwara et al., 2018). In this study, the effect of vegetation components in influencing erosional losses on fallow land is assessed.
Vegetation composition and structure in different successional stages carry out essential roles in shielding the soil from the direct impact of rainwater, regulate soil erosion processes, suppress the movement of surface runoff and allow rainwater to infiltrate the soil (Iwara, 2018; Vasquez and Sheley, 2018). It also performs a vital function of enhancing and maintaining soil nutrients thereby preserving soil structure. For example, vegetation shields the soil underneath from rapid drying, compaction, and leaching by rain (Ai et al., 2017). However, the ability of vegetation to effectively suppress soil erosion depends principally on existing vegetation parameters in relation to fallow history (years of fallow) and the type of vegetation. High density of plant and the establishment of closed canopy cover in the different phases of ecological succession play a vital role in facilitating the canopy hydrological performance of plant communities to reduce the of velocity runoff. In areas where vegetation mostly ground cover is sparse and scanty, the amount of sediment and nutrient element loss may possibly be massive, which may delay the time of optimum nutrient accretion in the soil (Iwara, 2013; Ai et al., 2017; Jakab et al., 2017).

Literature is rich on soil erosion, sediment and nutrient loss, but majority of the studies available were carried out on cropping system, plantations and under 
individual species in vegetation patches (Daura, 1995; Zhenhong, 2004; Vásquez-Méndez et al., 2010; Haridjaja, 2012; Ai et al., 2017; Jakab et al., 2017). However, information on runoff and sediment loss during the process of nutrient restoration on abandoned farmlands of different fallow ages is poorly documented in the literature of forest ecology. The aim of this study was to evaluate runoff and sediment loss in abandoned farmlands in a part of the rainforest belt of south-southern Nigeria. The specific objectives were to determine the amounts of runoff and sediment loss using runoff plots.

\section{MATERIALS AND METHODS}

Study area: The study was carried out in Agoi-Ekpo, in Yakurr Local Government Area of Cross River State. Its geographical coordinates are $5^{\circ} 50^{\prime} 0{ }^{\prime \prime}$ North and $8^{\circ} 16^{\prime} 0^{\prime \prime}$ East (Iwara, 2013). The area falls within the lowland of south-eastern Nigeria called the Cross River plain (Iloeje, 2001). The relief is gentle except in places where granite rises above the general level of the surface. Agoi-Ekpo falls in the humid equatorial climate of the tropics. It has the characteristics of the humid tropics which are high temperature, heavy rainfall and high relative humidity (Iloeje, 2001). The main soil is vertisol. The geology/parent material is of cretaceous sediments (Oden et al., 2012), while the topography of the study sites is generally uniform. The area has a rich vegetation and abundant wildlife.

Plot sampling: Fallows of 10-year 5-year, 3-year and abandoned farmland (with cassava after yam had been harvested) were identified and sampled using information on land use history (fallow ages) provided by the local farmers. In each identified fallow community, 10 plots of $20 \mathrm{~m} \times 20 \mathrm{~m}$ in dimension were randomly established. The established plots were used to obtain vegetation data. In the same way, a plot used for vegetation sampling for each fallow community was randomly selected from which runoff plot of $10 \mathrm{~m}$ $\mathrm{x} 4 \mathrm{~m}$ was constructed; from this runoff plot, surface runoff and sediment loss were obtained. The plots were constructed on similar terrain.

Soil sampling for particle size composition: Topsoil samples $(0-15 \mathrm{~cm})$ were collected from the fallow plots using a soil auger. In each fallow, 5 surface (0-10 $\mathrm{cm})$ soil samples were randomly collected with a soil auger and then composited. The soil samples were airdried and taken to the laboratory for analysis of soil physical properties. Particle size composition was determined using the hydrometer method (Bouyoucos, 1926).

Design and installation of runoff plots: Areas in which runoff plots were establishment had similar topography. Runoff plots were constructed using a wooden plank extending $10 \mathrm{~cm}$ below and protruding for $15 \mathrm{~cm}$ above the ground. All plots were $10 \mathrm{~m}$ long and $4 \mathrm{~m}$ wide giving a total area of 40 sq. metres $(0.004$ hectare). At the tail end of each plot, a gutter or channel for runoff collection was constructed at the outlet and storage container (.i.e. a 250-litre container drum) was installed to collect runoff after each rainstorm. The collection container was installed in a pit of $5 \mathrm{~m}$ by $5 \mathrm{~m}$ wide and $3.5 \mathrm{~m}$ deep. The PVC pipe performed the function of conveying the runoff and sediment into the collection container. Runoff amount in liters was measured following procedures described by Adediji (2006). The units of runoff were converted from litres to millimeters using the formula given by Vadas et al., (2002).

Data analysis: Data obtained were analyzed using tables, averages, independent samples test and OneWay Analysis of Variance (ANOVA) to determine if there are significant variation in textural soil properties and erosional losses (runoff and sediment loss) among the fallows.

\section{RESULTS AND DISCUSSION}

Soil physical properties: Soil textural information of the abandoned farmland and fallow soils is depicted in Table 1. This data was used to know the soil types of the respective plots. Sand content was comparatively high in the 5-year fallow, followed by the 3-year fallow and then the 10-year fallow, but low in the abandoned farmland with values of $64.2 \%, 63.0 \%$, $62.4 \%$ and $60.6 \%$ respectively. This indicates that the soils of the fallows and abandoned farmland are principally sandy; with sand constituting more than $60 \%$ of the inorganic mineral fragment. Silt content in treatments was relatively high in the abandoned farmland, followed by the 10-year and 3-year fallows, while the 5-year fallow had low silt content with values of $23.0 \%, 22.2 \%, 22.2 \%$ and $21.2 \%$ respectively. In addition, clay proportion happened to be relatively high in the abandoned farmland and low in the 3-year fallow with values of $16.4 \%$ and $14.6 \%$ respectively. Analysis of Variance result indicates that sand $(\mathrm{F}=0.758, \mathrm{p}>0.05)$, silt $(\mathrm{F}=1.223, \mathrm{p}>0.05)$ and clay $(\mathrm{F}=0.420, \mathrm{p}>0.05)$ contents do not vary among the plots. This implies that the soils of the fallow plots and abandoned farmland are similar. The textural analysis of the respective fallow plots indicates that soils in the 10-year, 5-year, 3-year and abandoned farmland are sandy loam with sand accounting for above $60 \%$ of the inorganic mineral fragment.

Sandy loam soils are known to be well-drained as such, soil erosion processes is expected to be minimal due to the appreciable amount of sand and silt compared to sandy clay soils. It is obvious that greater percentage 
of the rainwater would be absorbed by the coarse textured and more permeable soils of the fallow and farmland soil. The presence of embedded gravel, sand content and the percentage of grass cover as well as the presence of free pebbles and blocks, the silt, clay and organic matter contents of the soil among others are acknowledged by scholars to influence runoff and soil losses (Descroix et al., 2001). In a related study, (Smaeil and Marl, 2002; Ramezanpour et al., 2010) studied the influence of silt, sand and clay fractions on soil erosion. They reported that there was no logical relationship between these soil physical properties and erosion. The obtained information on soil textural properties of the fallows and farmland plots therefore indicates the soils are relatively similar which means that variation in runoff, sediment and nutrient losses on the plot treatments may be attributed to the differences in vegetation characteristics and fallow ages.

Table 1: Physical properties of the studied fallow soils ${ }^{\mathrm{a}}$

\begin{tabular}{lllll}
\multicolumn{5}{c}{ Table 1: Physical properties of the studied fallow soils ${ }^{\mathrm{a}}$} \\
\hline Soil & Fallows & & \\
\cline { 2 - 5 } properties & 10-year & 5-year & 3-year & Abandoned farmland \\
\hline Sand (\%) & $62.4 \pm 0.92$ & $64.2 \pm 2.35$ & $63.0 \pm 2.25$ & $60.6 \pm 0.71$ \\
Silt $(\%)$ & $22.2 \pm 1.02$ & $21.2 \pm 1.39$ & $22.2 \pm 1.62$ & $23.0 \pm 2.06$ \\
Clay (\%) & $15.4 \pm 1.40$ & $14.6 \pm 1.11$ & $14.8 \pm 0.75$ & $16.4 \pm 1.57$ \\
\hline \multicolumn{5}{c}{ Values are means \pm standard errors }
\end{tabular}

Runoff dynamics on abandoned farmland and fallow vegetation: The annual runoff amount across the plots (treatments) ranged from $6.63 \mathrm{~mm}$ to $28.84 \mathrm{~mm}$. The runoff loss from the 10-year fallow was negligible with annual runoff value of $6.63 \mathrm{~mm}$. The annual runoff in other plots (treatments) was $15.83 \mathrm{~mm}, 28.84 \mathrm{~mm}$ and $25.30 \mathrm{~mm}$ for 5-year fallow, 3-year fallow and abandoned farmland respectively (Table 2 and Fig. 1). The lowest runoff was recorded on the 10-year plot, while the 5-year plot had the highest runoff. The differences in runoff volumes on all the treatments indicate that runoff is not vegetation dependent, as runoff amount happened to be more on the 5-year fallow plot than on the 3-year fallow and abandoned farmland plots. The results of analysis of variance in Table 2 of the storm runoff losses from the various treatments revealed significant variation in runoff amount among the treatments at $(\mathrm{F}=16.089 ; \mathrm{p}<0.05)$. The variation in runoff volume across the fallow ages was attributed to the differences in land cover mostly vegetation and ground cover in intercepting and reducing the kinetic force of rainfall. Furthermore, result of Post Hoc Test of multiple comparison of runoff between the treatments using the Least Square Difference (LDS) revealed that runoff volume on the 5-year plot, 3-year plot and abandoned farmland differed significantly from the value recorded on the 10-year plot (Table 2 and Fig. 1).

The amount of runoff on the 3-year plot also differed significantly from the values recorded on the 10-year, 5 -year and abandoned farmland plots. On the 5-year plot, runoff volume differed significantly from the values recorded on the 10-year and 3-year plots but did not differ from the values recorded on the abandoned farmland plot. This also applied on the abandoned farmland. The abandoned farmland and 5-year fallow plots displayed the same trend; this may be attributed to the sparse crown cover with canopy gaps, little litter depth and scanty herbaceous cover in these plots. With the continuous rain, it was observed that little storm resulted in plenty of runoff, and most times with very little sediment. Invariably, the wetness of the soil by previous storms made runoff to be experienced even with little rainstorms. For instance, $5.6 \mathrm{~mm}$ of rainfall generated runoff and negligible quantity of soil was eroded on the 5-year and abandoned farmland plots respectively. Since, the soil was already soaked by previous storms, any storm thereafter, took less than a minute to generate runoff depending mostly on the intensity of the rain. The 5-year fallow plot was observed to be most effective in generating runoff followed by the cultivated farmland. This was attributed to the scanty undergrowth and canopy gaps.

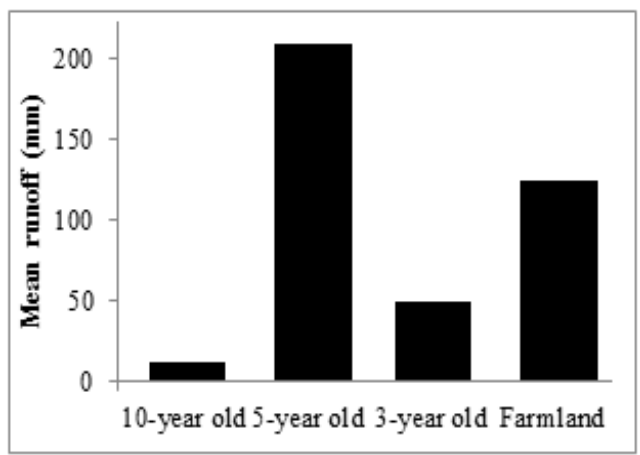

Fig. 1: Runoff volume across plots

However, the change in vegetation characteristics was observed to have substantial effects on the amount of runoff experienced across the plots, as there was a gradual reduction in soil erosion with the growth in vegetation (herbaceous cover and crown cover) mostly on the 3-year fallow and abandoned farmland plots. In the March to June when the rains started, runoff was 
high on the farmland plot, but its volume was observed to gradually decrease with the rains, as vegetation began to be established, since yams were harvested from the farmland and cassava was left to mature. The rapid increase in herbaceous cover as well as the sprouting of cassava leaves on the abandoned farmland following the full commencement of the rains helped to reduce runoff depth in the latter stage of the experiment. The growth in herbaceous cover on the 5year fallow plot was slow, with almost no noticeable difference between the ground cover in March and November. The 10-year fallow plot absorbed a greater percentage of the rainwater and as expected, it offered the best protection having recorded the lowest amount of runoff. This may be explained by the effective interception and attenuation of rainfall by the well developed and dense crown cover. However, the runoff volume recorded on all the treatments were below the values reported by Hidayat et al., (2012) on shrubs $(72.1 \mathrm{~mm})$, maize $(66.2 \mathrm{~mm})$ and natural forest $(31.1 \mathrm{~mm})$ plots respectively. The runoff values reported were also below the values reported by Lal, (1989) in Ilorin, Nigeria. Lal (1989) reported values of $44 \mathrm{~mm}, 11 \mathrm{~mm}$ and $61 \mathrm{~mm}$ for bush fallow, traditional farming and no-till respectively. The differences in runoff volumes among the studies are attributed to the type of land use employed in the respective studies as well as on the duration of experiment.

Table 2: Descriptive statistics of runoff amount $(\mathrm{mm})$ in the

\begin{tabular}{lccc}
\multicolumn{4}{c}{ treatments } \\
\hline Fallow treatments & $\mathbf{N}$ & Sum & Mean \\
\hline 10-year fallow & 61 & 6.63 & 0.11 \\
5-year fallow & 61 & 28.84 & 0.47 \\
3-year fallow & 61 & 15.83 & 0.26 \\
Abandoned Farmland & 61 & 25.30 & 0.41 \\
Rainfall & 61 & 1360.0 & 22.30
\end{tabular}

Variation in runoff amount was significant at 5\% alpha level ( $F$ value $=16.089 ; D F=3 / 240$ )

Sediment losses: The total sediment losses for the different plots (treatments) are shown in Table 3. It showed that the 5-year fallow plot yielded the highest sediment loss with a mean value of $209.24 \mathrm{~kg} \mathrm{ha}^{-1} \mathrm{yr}^{-}$ ${ }^{1}$, while the 10-year fallow yielded the lowest amount of eroded soil with mean sediment value of $12.43 \mathrm{~kg}$ $\mathrm{ha}^{-1} \mathrm{yr}^{-1}$. The 3-year and abandoned farmland plots generated sediment with mean values of $50.54 \mathrm{~kg} \mathrm{ha}^{-1}$ $\mathrm{yr}^{-1}$ and $124.68 \mathrm{~kg} \mathrm{ha}^{-1} \mathrm{yr}^{-1}$ respectively (Table 3 and Fig. 2). This indicates that sediment loss like runoff is closely influenced by land cover mostly natural vegetation or crops. The pattern of sediment loss among the fallow treatments followed a trend similar to that of runoff, with the 5-year fallow yielding the highest erosional loss. The results of analysis of variance in Table 3 indicated significant variation in the amount of eroded soil among the plots at $(\mathrm{F}=$ $6.355, \mathrm{p}<0.005)$. In addition, the Post Hoc Test of multiple comparison of sediment loss among the treatments showed that sediment loss on the 10-year plot did not differ from the amount recorded on the 3yearr fallow, but differed significantly from those recorded on the 5-year and abandoned farmland plots.

On the 5-year plot, the amount obtained differed significantly from the values recorded on the 10-year and 3-year plots, but did not differ from those on the abandoned farmland; while the amount of eroded sediment did not differ from those on the 10-year and 3 -year plots. Also, the quantity of sediment on the 3year fallow only differed from those recorded on the 5-year plot. This implies that the amount of sediment loss yielded on the 10-year and 3-year is relatively the same; this also applies to the amount recorded on the 5-year and abandoned farmland plots. Nevertheless, for the 5-year plot, sediment loss differed significantly from the values recorded on the 10-year and 3-year old plots, whereas, on the abandoned farmland, sediment loss differed significantly from those on the 10-year old plot (Table 3 and Fig. 2). The difference in sediment loss among the plots was attributed to variation in crown cover, litter accumulation and herbaceous cover as the experimental plots were located on similar soil, slope and exposed to the same rainfall events as earlier discussed.

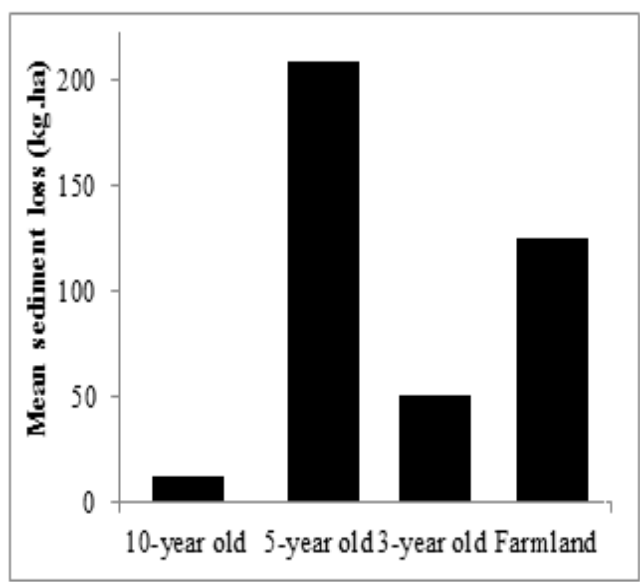

Fig. 2: Sediment loss across plots

The low sediment loss recorded on the 10-year fallow plot may be as a result of the reduction in run-off and enhancement of rainfall infiltration; while the very high sediment losses on the 5-year and abandoned farmland plots may be blamed on the existence of sparse ground cover percentage as well as low litter contents. Sediment loss on the 5-year, 3-year plot and abandoned farmland was observed to increase with 
runoff volume. This is consistent with the observations of earlier and related studies, like those of Benik et al., (2003), Egharevba (2004) and Ai et al., (2017) when they stated that sediment yield generally increased with runoff volume. The amount of sediment loss observed across the treatments is higher than the values reported by Daura (1995) in University of Ibadan, Nigeria, and Avwunudiogba (2000) across different tillage practices in southwestern Nigeria. The differences in rainfall amounts and treatments used may be responsible for the observed variation. Avwunudiogba (2000) study lasted for 5 months (March to July, 1994) and soil loss values ranged from 276 to $7,672 \mathrm{~kg} \mathrm{ha}^{-1}$ for fallow (control) and maize planted on no-tillage respectively. As rightly argued above, differences in rainfall amounts and frequency as well as the duration of study may be attributed to the variation in sediment/soil loss recorded. In this study, 54 rainstorms that generated measurable sediment on all the plots were evaluated, while the study by Daura (1995) and Avwunudiogba (2000) recorded 23 and 43 rainfall events that generated soil loss respectively. The differences in measured eroded soil may also be attributed to the sizes of runoff plots.

Table 3: Descriptive statistics on sediment loss $\left(\mathrm{kg} \mathrm{ha}^{-1}\right)$ in the

\begin{tabular}{lccc}
\multicolumn{4}{c}{ treatments } \\
\hline Plot treatment & $\mathrm{N}$ & Sum & Mean \\
\hline 10-year old & 54 & 671.0 & 12.43 \\
5-year old & 54 & 11299.05 & 209.24 \\
3-year old & 54 & 2729 & 50.54 \\
Farmland & 54 & 6732.68 & 124.68
\end{tabular}

Variation in sediment loss was significant at 5\% alpha level ( $F$ value $=6.355 ; D F=3 / 212$

The results show a clear variation in the amount of soil erosion and associated losses among the plots. The study shows that greater proportion of the annual rainfall is absorbed by soils on the 10-year fallow plot due to its dense canopy structure and developed root system. The 5-year plot yields the highest erosional losses (runoff, sediment and nutrient loss), while the 10 -year plot has the lowest. The variation in runoff, sediment and nutrient loss among the plots lends support to earlier and related studies, like those of Puigdefabregas (2005), Vásquez-Méndez et al., (2010), Ai et al., (2017) and Jakab et al., (2017) that land area covered with vegetation helps to reduce runoff and sediment loss. This therefore means that the increase in tree density and vegetal cover during nutrient restoration in fallows results in the decrease in soil erosion and its associated losses. The abandoned farmland and 5-year fallow plots display similar trend in runoff depth which may be attributed to the similarities in vegetation characteristics (sparse herbaceous cover and low litter depth) mostly at the onset of the experiment.

The low runoff volume experienced on the 10-year and 3 -year plots is attributed to the rainfall energy interception by the dense vegetation cover and ground cover (density of herbs) in the respective plots, thus increasing water infiltration and storage and a general maintenance of good soil structure. This implies that increase in surface cover effectively reduces runoff (Ali et al., 2007; Huang et al., 2017). This assertion is consistent with those of Gyssels et al., (2005) and Huang et al., (2017) that vegetation controls soil erosion and its associated losses by means of its canopy, roots and litter components. They further argued that the composition, structure and growth pattern of the plant community influence soil erosion. The vegetation structure (crown cover, girth and basal cover) on the 10-year fallow and its high litter depth help to intercept a significant amount of rainwater, which afterward moves down as steam flow to the soil, thus, increasing infiltration and diminishing the potential for runoff (Puigdefabregas, 2005).

In addition, the existence of tree/shrub density and the subsequent development of root system make it possible for a significant amount of the rainwater to be absorbed in the soil of the 10-year fallow (Nobel, 1987), thereby reducing the amount available for runoff. This implies that the maintenance of adequate surface cover helps to reduce runoff velocity. On the other hand, the high runoff volume recorded on the abandoned farmland plots mostly at the early stage of the experiment (March to June) may be attributed to the scanty undergrowth (density of herbs) and absence of adequate vegetation cover to intercept the rainwater. However, the considerable reduction in runoff depth on the abandoned farmland in the later period (July to November) than on the 5-year fallow plot is attributed to the sprouting of cassava and rapid growth of herbs mostly Chromolaena odorata. Similar observation was reported by Nobel (1987) and Chen et al., (2007). The canopy gaps (open canopy structure) on the 5-year fallow did not provide adequate cover for controlling soil erosion, as it gives way for raindrop to strike directly on the topsoil. This again corroborates the findings of Solaimani et al., (2009), Su et al., (2010) and Jakab et al., (2017) that sites with sparse surface cover (vegetation and herbaceous cover) can increase soil erosion.

The high runoff volume experienced on the 5-year fallow implies that vegetation cover alone does not afford the soil adequate cover, but the availability of herbaceous cover potentials (density of herbs). The herbaceous cover on the 5-year fallow was scanty. The 
scanty herbaceous cover may be attributed to its previous land use history of unintended bush fire resulting in the burning of undergrowth. This had profound impact on the rapid establishment and growth of ground cover because the rate of was rather slow. This is consistent with the finding of Maret and Wilson (2005) that fire either unintended or prescribed burning have profound impacts on establishment rates by breaking seed dormancy and altering microenvironmental conditions for germination and growth. Fire is also acknowledged to decrease plant biomass (Matayaya et al., 2017). The rapid growth in herbaceous species and subsequent herbaceous cover on the abandoned farmland and 3-year fallow following the rains affords the soil adequate cover to minimize erosional losses. The studies of Daura (1995) and do Nascimento et al., (2018) showed that herbaceous cover (undergrowth), plant residues and vegetation cover increases the porosity of the upper horizon of the soil and hence its infiltration capacity.

On runoff, the study shows that rainfall is the determinant of surface runoff on all the plots. This is because little storm resulted in runoff, and most times with very little sediment generated. For instance, with $5.2 \mathrm{~mm}$ of rainfall, runoff of 0.04 to $0.07 \mathrm{~mm}$ and negligible quantity of soil was eroded on the 5-year fallow and abandoned farmland plots respectively. The wetness of the soil by previous storms is therefore responsible for the runoff experienced on all the plots. This is so as wet soil is observed to have lower infiltration rates since the pore spaces are already filled with water. This pattern of runoff is also reported in a related study by Makanjuola et al., (2011) that most runoff and soil loss events take place at the periods of high rainfall when soil is very moist. Monthly variation in runoff volume reveals that the months of July, August and September experience the highest amount of runoff on all the plots. Particularly, July experienced the highest surface runoff on the 5-year, 3 -year and abandoned farmland treatments, while the highest amount of runoff on the 10-year fallow plot was recorded in September. This is not surprising as these months are usually associated with heavy rainstorms and more frequent rainfall events. These months have also been reported by earlier studies. For instance, Okonkwo and Mbajiorgu (2010) identified July through September as months with the highest daily rainfall. In a related study, Ologunorisa and Tersoo (2006) identified August as the month with the most frequent events of daily rainfall.

Conclusion: The study reveals that age of fallow to some extent does not translate into reduced soil erosion, as fallows with inadequate herbaceous cover potentials are less effective in suppressing soil erosion and it associated losses. This therefore implies that vegetation cover alone does not afford the soil adequate cover. On this note, farmers should try as much as possible to maintain good herbaceous cover in fallows with scanty herbaceous cover to reduce unproductive loss of rich and nutrient laden topsoil. Maintaining continuous undergrowth (herbaceous cover) could help to deal with problems of ecological imbalance caused by forest removal during land cultivation.

\section{REFERENCES}

Adediji, A (2006). Land use, runoff, and slopewash in the opa reservoir basin, southwestern Nigeria. $J$. Environ. Hydrology, 14 (3): 1 - 8.

Ai, N; Wei, T; Zhu, Q; Qiang, F; Ma, H; Qin, W (2017). Impacts of land disturbance and restoration on runoff production and sediment yield in the Chinese Loess Plateau. J Arid Land, 9(1): 76-86.

Ali, I; Khan, F; Bhatti, AU (2007). Soil and nutrient losses by water erosion under mono-cropping and legume inter-cropping on sloping land. Pakistan J. Agric. Res, 20 (3 - 4): 161 - 166.

Avwunudiogba, A (2000). A comparative analysis of soil and nutrient losses on maize plots with different tillage practices in the Ikpoba River Basin of south-western, Nigeria. The Nigerian Geographical Journal, 3 \& 4: 199 - 207.

Benik, SR; Wilso, BN; Biesboer, DD; Hensen, B; Stenlund, D (2003). Evaluation of erosion control products using natural rainfall events. $J$. Soil Wat. Conserve. 58 (2): 83-85.

Bouyoucos, GJ (1926). Hydrometer Method for Making Particle Size Analysis of Soils. Soil Science Society of America Proceedings, 26, 464-465.

Chen, L; Huang, Z; Gong, J; Fu B; Huang, Y (2007). The effect of land cover/vegetation on soil water dynamic in the hilly area of the loess plateau, China. Catena, 70, $200-208$.

Daura, MM (1995). Comparative analysis of runoff, soil and nutrient loss under different cropping systems. Ph.D. Dissertation, Department of Geography, University of Ibadan, Nigeria.

Descroix, L; Viramontes, D; Vauclin, M; Gonzalez Barrios, JL; Esteves, M (2001). Influence of soil surface features and vegetation on runoff and 
erosion in the Western Sierra Madre (Durango, Northwest Mexico). Catena, 43:115 - 135.

do Nascimento, CDV; Costa, MCG; Toma, RS; Mota, JCA; Menezes, AS; Cooper, M (2018). Soil structure and porous system in response to plant components of an agrosilvopastoral system. $J$. Agri. Sci., 10 (5): 63 - 78.

Egharevba, NA (2004). Evaluation of sediment yield from agricultural fields during natural rainfall events. J. Sustain.Trop. agric. Res. 11, $104-$ 108.

Ezemonye, MN; Emeribe, CN (2012). Rainfall erosivity in southeastern Nigeria. Ethiopian $J$. Environ. Stud. Manage. 5 (2): 112 - 122.

Gyssels, G; Poesen, J; Bochet, E; Li, Y (2005). Impact of plant roots on the resistance of soils to erosion by water: A review. Progress in Physical Geography, 29: 189-217.

Haridjaja, O (2012). Sediment enrichment ratio and nutrient leached by runoff and soil erosion on cacao plantation. Journal of Tropical Soils, 17 (1): $67-74$.

Hidayat, Y;Murtilaksono, K; Sinukaban, N (2012). Characterization of surface runoff, soil erosion and nutrient loss on forest-agricultural landscape. Journal of Tropical Soils, 17 (3): 259 $-266$.

Huang, J; Kang, Q; Yang, JX; Jin, PW (2017). Multifactor analysis and simulation of the surface runoff and soil infiltration at different slope gradients. IOP Conf. Series: Earth and Environmental Science, 82, 1 - 12.

Iloeje, NP (2001). A new geography of Nigeria. New Revised Edition. Longman Nigeria PLC. 200 p.

Iwara, AI (2013). Runoff and soil loss of vegetative fallow and farmland of south-eastern Nigeria. Kasetsart J. (Natural Science), 47: 534 - 550.

Iwara, AI; Njar, GN; Ogundele, FO; Tokula, AE (2018). Influence of vegetation characteristics on nutrient loss in the rainforest belt of Agoi-Ekpo, Cross River State, Nigeria. J. Appl. Sci. Environ. Manage. 12 (7) 1043 - 1050.

Iwara. AI (2014). Evaluation of the variability in runoff and sediment loss in successional fallow vegetation southern Nigeria. Soil \& Water Res. 9 (2): $77-82$.

Jakab, G; Madarász, B; Szabó, JA; Tóth, A; Zacháry, D; Szalai, Z; Kertész, A; Dyson, J (2017). Infiltration and soil loss changes during the growing season under ploughing and conservation tillage. Sustainability, 9, 1726.

Jourgholami, M; Labelle, ER; Feghhi, J (2017). Response of runoff and sediment on skid trails of varying gradient and traffic intensity over a twoyear period. Forests, 8, 472; doi: $10.3390 /$ f8120472

Lal, R (1989). Cropping systems effects on runoff, erosion, water quality, and properties of a savanna soil at Ilorin, Nigeria. Proceedings of the Baltimore Symposium, May, IAHS Publ. No. 184: 67 - 74.

Makanjuola, MB; David, J; Makar, TA; Olla, OO; Ahaneku, IE (2011). Evaluation of runoff and sediment loss under different tillage systems. Continental Journal of Water, Air and Soil Pollution, 2: 20-24.

Maret, MP; Wilson, MV; (2005). Fire and litter effects on seedling establishment in western Oregon upland prairies. Restoration Ecology, 13 (3): $562-568$.

Matayaya, G; Wuta, M; Nyamadzawo, G (2017). Effects of different disturbance regimes on grass and herbaceous plant diversity and biomass in Zimbabwean dambo systems, International Journal of Biodiversity Science, Ecosystem Services \& Management, 13 (1): 181-190.

Nobel, PS (1987). Environmental biology of Agaves and Cacti. Cambridge University Press, University of California. Los Angeles, CA, USA.

Oden, MI; Okpamu, TA; Amah, EA (2012). Comparative analysis of fracture lineaments in Oban and Obudu Areas, SE Nigeria. Journal of Geography and Geology, 4 (2): 36 - 47.

Okonkwo, GI; Mbajiorgu, CC (2010). Rainfall intensity-duration-frequency analyses for south eastern Nigeria. Available online: http://www.cigrjournal.org/index.php/Ejounral/ article/viewFile/1304/1280 (Accessed: 9/4/ 2014).

Ologunorisa, TE; Tersoo, T (2006). The changing rainfall pattern and its implication for flood 
frequency in Makurdi, northern Nigeria. Journal of Applied Sciences and Environmental Management, 10 (3): 97-102.

Puigdefabregas, J (2005). The role of vegetation patterns in structuring runoff and sediment fluxes in Drylands. Earth Surface Processes and Landforms, 30, 133-147.

Ramezanpour, H; Esmaeilnejad, L; Akbarzadeh L (2010). Influence of soil physical and mineralogical properties on erosion variations in Marlylands of Southern Guilan Province, Iran. International Journal of Physical Sciences, 5(4): $365-378$.

Smaeil, ZH. Marl (2002). Soils and different types of erosion in Iran. 17th WCSS, Thailand, 22351: 18.

Solaimani, K; Modallaldoust, S; Lotfi, S (2009). Investigation of land use changes on soil erosion process using geographical information system. International Journal of Environment Science and Technology, 6: 415-424.

Su, ZA; Zhang, JH; Nie, XJ (2010). Effect of soil erosion on soil properties and crop yields on slopes in the Sichuan Basin, China. Pedosphere, 736746.
Vadas, PA; Sims, JT; Leytem, AB; Penn, CJ (2002). Modifying FHANTM 2.0 to estimate phosphorus concentrations in runoff from Mid-Atlantic coastal plain soils. Soil Sci. Soc. Am. J. 66, 1974 - 1980.

Vasquez, EA; Sheley, RL (2018). Developing diverse, effective, and permanent plant communities on reclaimed surface coal mines: restoring ecosystem function. Journal American Society of Mining and Reclamation, 7 (1): 77 - 109.

Vásquez-Méndez, R; Ventura-Ramos, E; Oleschko, K; Hernández-Sandoval, L; Parrot, JF; Nearing, MA (2010). Soil erosion and runoff in different vegetation patches from semi-arid central Mexico. Catena, 80: 162-169.

Zhenhong, W (2004). Relationship between Plant Species Diversity and Soil Erosion on Different Secondary Succession phases of a semi-Humid Evergreen Broad-leaved Forest. Paper Presented at the $13^{\text {th }}$ International Soil Conservation Conference, Brisbane. Available at: https://pdfs.semanticscholar.org/800f/60d41bca 61706790a3361333a3270fbe1b5e.pdf (Accessed: 18/11/2011). 